\title{
sciendo
}

10.2478/ewcp-2020-0015

\section{The Challenges of Translating The Adventures of Huckleberry Finn into Romanian}

\author{
ALEXANDRA MITREA \\ Lucian Blaga University of Sibiu, Romania
}

\begin{abstract}
A classic of American literature, Mark Twain's The Adventures of Huckleberry Finn has had a huge impact not only on American literature but also on world literature. Its bold and freshly creative style, its humor and the author's endless verve and vitality, the multifaceted and novel approach to life have all contributed to its success and popularity. However, Twain's greatest merit probably lies in the way in which he used language, crafting art out of the speech of ordinary people. His experiments with language, the vernacular in particular, have meant a huge step forward in American literature and have been a source of inspiration for many writers. However, the translation of the novel has generated huge challenges related to the linguistic register appropriate for the translation of the novel and the strategies for rendering dialect, the African-American one in particular. It has also divided Romanian translators with regard to the target readership the original novel addressed: children, adults or both.
\end{abstract}

Keywords: translation theory, literariness, dialect, vernacular, standard, non-standard, style, orthography, Romanian translation

A classic of American literature, Mark Twain's The Adventures of Huckleberry Finn has had a tremendous impact not only on American literature but also on world literature. Its bold and 
freshly creative style, its humor and the author's endless verve and vitality, the multifaceted and novel approach to life have all contributed to its success and popularity. However, Twain's greatest merit probably lies in the way in which he used language, crafting art out of the speech of ordinary people. His experiments with language, with the vernacular in particular, have meant a huge step forward in American literature and have been a source of inspiration for many writers. The masterful way in which he captured American realities - among which the still troublesome race relations in the post-Reconstruction South, the way in which he satirized the foundations of that society, the hypocrisy of people in religion or education, the description of setting in which local color is preeminent, to say nothing of the intertextual character of his work - allusions to fundamental myths and stories such as the Garden of Eden suggested by Jackson's island, references to Shakespeare's 'Romeo and Juliet' story in the elopement of lovers from their families, to say nothing of the parodies of Shakespearean pieces by 'the king' and 'the duke,' all these add to the significance of a novel which is more than just a series of adventures on the Mississippi river. No wonder that Ernest Hemingway declared unhesitatingly that "all modern American literature comes from one book by Mark Twain called Huckleberry Finn. ... There has been nothing as good since" (22), or that William Faulkner called Twain "the father of American literature" (qtd. in Jelliffe 88).

In his seminal book The Liberal Imagination, Lionel Trilling points out the merits of Twain's prose, emphasizing the novelty residing in the masterful use of colloquial speech: "The prose of Huckleberry Finn established for written prose the virtues of American colloquial speech... It has something to do with ease and freedom in the use of language." Furthermore, Trilling proclaims Twain a master of style, highlighting the distinctive features - its orality in particular - that have made the writer a landmark in American literature: "Most of all it has to do with the structure of the sentence, which is simple, direct and fluent, maintaining the rhythm of the word-groups of speech and the 
intonations of the speaking voice... [Twain] is the master of the style that escapes the fixity of the printed page, that sounds in our ears with the immediacy of the heard voice" (91-92).

Despite the enormous popularity the novel has enjoyed in the course of time, the book has been extremely controversial and has been the fifth most frequently challenged book in the United States during the 1990s, in keeping with the American Library Association. ${ }^{1}$ The controversy started immediately after the novel was published in 1884. A year later, the public library in Concord, Massachusetts, banned the book on the grounds of the title character being a bad example for children. In 1907, both The Adventures of Tom Sawyer and Huckleberry Finn were banned from libraries for the inappropriate behavior of their title characters. Fifty years later, the National Association for the Advancement of Colored People pronounced the book as racially offensive, and the novel was subsequently removed from the required reading lists in various states. Parents and teachers alike contested the presence of the book in the reading list time and again. Some of them even sued the school districts over the teaching of the book in the classroom, reacting against the novel's offensive language, the use of the word "nigger" in particular. So much so that in 2011, a new English edition of Twain's Huckleberry Finn came out in which the word "nigger," which appears 219 times in the original version of the book published in 1884, was removed. Mention should also be made of a commercial broadcast television (CBS), which removed all references to slavery and did away with the character of Jim altogether in 1955, in an effort to avoid all controversial issues in its televised version of the novel.

It goes without saying that such a highly controversial book posed great difficulties to translators who had to decide, first of all, who their target readership was. Many translators approached it as a book for children and felt the need to expurgate the language and clarify meanings. However, Twain himself reacted to the book being regarded as children's literature and claimed that he wrote it for adults: "I am greatly troubled by what you say. I wrote 'Tom Sawyer' \& 'Huck Finn' for adults exclusively, \& it always 
distresses me when I find that boys and girls have been allowed access to them. The mind that becomes soiled in youth can never again be washed clean" (qtd. in Kehe).

Secondly, and this was the greatest challenge translators faced, has been how to deal with the language employed by the writer and with his style in general. The old Italian saying traduttore, traditore has proven particularly apt when translating Twain's writings because what represents one of his greatest achievements - the way in which he handles language to suggest the speech of ordinary people in the state of Missouri - becomes one of the greatest challenges for translators. ${ }^{2}$ Twain was very much concerned with the language he used in his writings so much so that, in the explanatory note to the novel, the writer drew the reader's attention to the seven dialects he employed in his work purposefully, as a way of portraying characters, in relation to their regional, social class or racial backgrounds:

In this book a number of dialects are used, to wit: the Missouri negro dialect; the extremest form of the backwoods Southwestern dialect; the ordinary "Pike County" dialect; and four modified varieties of this last. The shadings have not been done in a haphazard fashion, or by guesswork; but painstakingly, and with the trustworthy guidance and support of personal familiarity with these several forms of speech.

I make this explanation for the reason that without it many readers would suppose that all these characters were trying to talk alike and not succeeding. (xi)

Twain had been deeply preoccupied with the language of his characters and had taken pains to approximate the various dialects which were spoken in the South at that time, especially the African-American dialect. Shelley Fisher Fishkin, an authoritative voice in Twain scholarship, author of the famous book Was Huck Black?: Mark Twain and African-American Voices (1993), delves into the writer's interest in African-American voices and quotes Kate Leary, Samuel Clemens' servant for 30 years, who delineated 
a remarkable evening wherein the writer was in the spotlight, due to his preoccupation with African-American spirituals:

Katy Leary, a servant of the Clemens family, reports that one evening as a group of guests were sitting in the music room looking out at the moonlight at the home of the Charles Dudley Warner, a neighbor in Hartford, Twain 'suddenly got right up without any warning' and began to sing 'negro Spirituals.' He sang 'low and sweet,' Leary recalled, and 'became kind of lost in it.' When he came to the end of the song, 'to the Glory Halleluiah, he gave a great shout - just like the negroes do - he shouted out the Glory, Glory, Halleluiah!' Those who were there said that 'none of them would forget it as long as they lived.' (6)

This story illustrates Twain's deep preoccupation with the black voices of his childhood, the Missouri African-American dialect in particular, and his attempt at imitating it in the novel. As Arthur G. Pettit pointed out, "Twain was constantly practicing his skill with black vernacularisms - playing with alternative spellings and pronunciations, honing the sound and the nuance to the highest possible pitch of perfection. His notebooks of the eighties and nineties are filled with dialect scribblings" (128).

The extent to which Twain managed to imitate this dialect, is, however, highly debatable and critics have doubted whether Twain really approximated the African-American dialect. Sumner Ives, for instance, convincingly argues that "nearly all examples of literary dialect are deliberately incomplete," because the author is an artist, not a linguist or a sociologist, his purpose being literary rather than scientific (qtd. in Berthele 589). Upon eloquently analyzing the particularities of the dialects noticeable in the novel, David Carkeet comes to disagree with Curt Rulon, author of a reference doctoral dissertation on dialects in Huckleberry Finn who had concluded that "there are only two dialects in the novel, one spoken by blacks and the other by whites" (qtd. in Carkeet 321). On the contrary, Carkeet claims and brings convincing dialectological arguments in support of his view that "we have nine distinct dialects spoken by white characters" (321). 
Be it as it may, whether there are nine distinct dialects or six, or just two, it is clear that the translator should strive to reflect this dialect-based differentiation between characters. The main purpose behind the use of dialects is, beyond the shadow of a doubt, to create the illusion of authenticity, not only of persons but also of geographical and historical contexts. This illusion of authenticity should be recreated by the translator, if s/he is to be faithful to the original. In addition to this, the translator should also do his best to domesticate the original, so as to construct "the other" as "the recognizable, the familiar, even the same," as Lawrence Venuti argued in his seminal book The Translator's Invisibility:

The aim of translation is to bring back a cultural other as the recognizable, the familiar, even the same; and this aim always risks a wholesale domestication of the foreign text, often in highly self-conscious projects where translation serves an appropriation of foreign cultures for agendas in the receiving situation, cultural, economic, political. Translation is not an untroubled communication of a foreign text, but an interpretation that is always limited by its address to specific audiences and by the cultural or institutional situations where the translated text is intended to circulate and function. (14)

With this conclusion in mind, we will set out to analyze the translations of The Adventures of Huckleberry Finn into Romanian. Mention should be made of the fact that the novel has enjoyed numerous translations into Romanian. The first one belongs to Petre Solomon and appeared in 1954, with Editura de Stat pentru Literatură şi Artă (State Publishing House for Literature and Art). Solomon's translation has been reprinted repeatedly (1955, 1957, $1964,1969,1975,1995)$ by many publishing houses. Apart from Solomon, the novel has also been rendered into Romanian by translators such as Alina Loredana Brebeanu, D. Colea, Monica Grecu, Monica Manolachi, Liviu Mateescu, Cristina Nicolaescu, Vittorio Em. Pascutti, Lucian Popa and Iulia Sterejean. All in all, over 30 editions of the novel have circulated which points to the high level of interest Twain's novel has aroused in Romania. The 
novel has also known numerous adaptations, such as those signed by Grecu Monica or Andreea Șerbănescu. The adaptations, however, do not make the object of our analysis.

Most of the Romanian translations of the novel approached it as children's literature, and, consequently, adapted the novel, based on the idea that children's knowledge of history or of racism is far more limited than that of adults. In addition to it, as B. J. Epstein aptly notes, upon reading Twain's works, children may not make much of the dialects the novelist resorted to: "given that the standard dialect is usually employed in schools and the media, children may indeed get the message that to speak using anything else is a negative sign."

What is surprising, however, is that one single translator has rendered Twain's Explanatory note into Romanian. It was only Mateescu who offered the Romanian reader a rendering of the note on dialects, but, interestingly enough, he failed to translate the novel accordingly, by suggesting some differences in the characters' speech to mark the distinction between standard and non-standard that Twain was so concerned with. Mateescu's characters speak all alike, in a Romanian language which is relatively standard, far from the coarse and inelegant speech, full of language mistakes, many Americans had reacted against. This is how Jim speaks in Mateescu's translation: "Îl știi pe negrul acela olog de un picior, al lui bătrânu' Brandish? Ei bine, și-a înjghebat o bancă zicând că cine pune un dolar, primește patru până la sfârșitul anului. Toți negri (sic) s-au prins dar nu aveau cine știe ce capital. Numai eu aveam cei mai mulţi bani, aşa că i-am cerut să îmi dea o dobândă mai mare" (57). Surprisingly enough, the uneducated Jim is credited with the word "capital" and uses a language which is quite standard.

A parenthesis is in place at this point of our discussion. In her article entitled "Literary Translation: Between Mediation and Interpretation," Ana-Karina Schneider correctly points to "the discrepancy between the respective linguistic registers [i.e. of English and of Romanian, our note] that are considered appropriate for various genres of communication" (109). The critic correctly 
notes that Romanian, a Romance language, "tends to be far more formal and standardised than contemporary English" especially in its written form; as a result, one notices the tendency "to refer to proper, sophisticated Romanian as 'literary,' and 'national language' designates the standard, cultured variety" (109). Furthermore, "formal phrasing stems from the determination to elevate the literary work - sometimes in spite of itself - to the position assigned a priori to 'Literature'; in the process, it modifies textural features such as the style of the communication and the narrative voice, for rhetorical purposes" (Schneider 109). This tendency is even more noticeable in the case of translations Schneider argues -, which inevitably pose "the issue of allegiance: does [the translation] aim at inclusion in the receiving canon, or can it risk shocking its readers by proposing foreign standards?" (109) Though internationally, the latter goal has been more influential, since it presupposes faithfulness to the original and encourages cultural diversity, the fact is that Romanian translators have favored "outdated notions of literariness," sacrificing the similarity of effect in the process, and neglecting the social function fulfilled by sociocultural lects - like literary genres - a function that Schneider describes as "interpellating the reader, and consequently instituting and conditioning a readership" (109). The Romanian theoretician pertinently argues that this interpellation is crucial to the definition of literary translation, as it facilitates the preservation of the relationship of the text to the linguistic and literary conventions of the target culture. The critic also draws attention to the importance of stylistic domestication which, far from pointing to a deficiency in the linguistic medium, is culture bound: "such choices made in translating circumscribe the role of translation in the definition of national identity in the receiving culture" (109-110).

Schneider's conclusions are particularly valid when analyzing the ways in which Twain's novel has been rendered into Romanian. Translators have neglected the issue of appropriate register and have evinced outdated notions of literariness which they prioritized to the detriment of authenticity. The truth is that the way in which Romanian translators dealt with the sociolinguistic 
issues present in the novel points to their take on the meaning of sociolinguistic difference, both with regard to the historical society portrayed in the novel and to the Romanian society for which they translated. It also mirrors the translators' perception of the role ascribed by Twain to the speech of the African-American characters he created in the novel (Berthele 589). It is quite obvious that Romanian translators approached the novel as a 'boy book,' a companion volume to its predecessor, The Adventures of Tom Sawyer, fact which is evident in their decision to render the Notice - it is present in almost all translations - ("Persons attempting to find a motive in this narrative will be prosecuted; persons attempting to find a moral in it will be banished; persons attempting to find a plot in it will be shot" (ix)) but to omit, interestingly enough, the Explanatory note. Their translation of the Notice, and their understanding of it as Twain's suggestions that one should look for no motive, no moral, no plot whatsoever in the novel, may have led them to the wrong conclusion that the book is nothing more than a funny, harmless adventure story of a raft journey on the Mississippi river. Such a simplistic approach to the book denies the powerful satire of white society which is over-present in the novel. Instead, as Fishkin argues, Twain's Notice should be interpreted as "his effort to deny any 'professed' or overt 'preaching' in Huckleberry Finn" (68), to deny any subversive intentions, all the more so as the issues the writer touches on, racism being preeminent, continue to be very sensitive.

Furthermore, Romanian translators' approach to the novel displays a tendency to preserve the norms of literary language: no differentiation between standard and non-standard forms, no effort at suggesting the fact that Jim speaks a socio-cultural lect which is different from the other characters, or that Huck's own lect is the vernacular type (to say nothing of the fact that Huck and the other characters speak an impeccable Romanian. Huck's father speaks flawlessly, creating a completely different effect than the one suggested by the original). The level of domestication in these translations is reduced (tending towards zero). We admit that finding target-language equivalents for dialectal or sociolectal 
speech in the source text is not an easy task, but it is the translator's duty to pay attention to content as well as to form, in order to achieve equivalence of effect. As Schneider correctly pointed out, the focus of Romanian translators has seldom been on translation as "a (creative) process or on the transfer of meanings or artefacts from other cultures into ours; rather, the completed translation was accepted as mediating access to a foreign text whose referentiality was largely confined to the culture it belonged to" (106).

It is surprising in this context that only two translators Nicolaescu and Brebeanu (though both of them omitting both the Notice and the Explanatory note) - have tried to domesticate Jim's speech. However, they neglected this aspect in the case of Huck or the other white characters, suggesting in this way that only Jim speaks non-standard language. Thus, the famous dialogue about King Solomon and his decision in the dead-baby argument is successfully rendered in Jim's case:

Buștean ăla o femeie, tu altă femeie, eu e Solemon și dolar ăsta e copil. Voi amândoi vreți bani. Ce face eu? Jim merge la vecini și află al cui banii și dau cui aparține, teafăr și nevătămat, cum oricine face? $\mathrm{Nu}$, eu taie banii în două și dă jumate ție, jumate altă femeie. Așa face Solemon cu copil. Acum eu întreabă la tine: cât valoare are jumate de bancnotă? Tu nu cumpăr nimic cu ea. Și cât valoare are jumate de copil? $\mathrm{Nu}$, Solemon nu înțelept deloc, ascultă Jim. (Brebeanu 84)

Nicolaescu's translation is also worth taking a look at as it adroitly domesticates Jim's speech. The translator resorts to violations of standard high Romanian, mainly in the field of grammar and syntax (lack of agreement in gender between noun and the qualifying adjective, lack of agreement in number between subject and predicate, wrong use of articles, etc.) which are characteristic of non-native speakers of Romanian, and which can be heard in the midst of larger ethnic minorities living in Romania:

- Aha!... Adev'rat. Bătrâna Jim uitat; aşa este, are dreptate. Jim gândește, așa un harem trebuie este mare ca o cârciumă, nu 
așa, Huck? Trebuie are toată casa plin cu mult odăi de copil, care toată ziua strig, toată ziua cert! Copil strig, femei cert! Bătrânu Solomon nu fost om ințelept, cum spune lume. $\mathrm{Nu}$ fost deloc înțelept, tu crede ce spune Jim. Om înțelept nu s-apuc clădesc un casă, și umplu cu femei și copil și şade în mijloc la tot gălăgie și tărăboi. Om înțelept nu face așa prostie. Om înțelept rămâne singur și clădesc un prăvălie mic ca să vinde țigări și whisky și închid prăvălie când el vrea are liniște. (103)

Apart from the level of morphological and syntactical structures where one notices violations of standard grammar and standard high Romanian, the domestication strategies employed in the translation process in Jim's case are also noticeable at the level of spelling. The spelling characteristics include sound/syllable loss, idiosyncrasies and spelling mistakes, stylistic variation in the lexicon, such as the use of colloquial and regional words, aspects that Raphael Berthele had also highlighted in his analysis of translations of the novel into German (591-592). However, the German theoretician points to a clear danger in using these nonstandard linguistic elements only in Jim's case: they "represent Jim as a socially, linguistically and even cognitively deficient" (592). This is also the case in Romanian where only Jim's speech exhibits deviations from the standard language, no regional and social dialectal variations being noticeable in the case of the other characters.

At the opposite pole, Huck sounds in Romanian as if his English were faultless, not a non-standard variety abounding in language mistakes. One should remember the point made by Janet Holmgren McKay who argues that "the kinds of errors that Huck makes are by no means haphazard... Twain carefully placed them to suggest Huck's basic illiteracy but not to overwhelm the reader." McKay further notes that "non-standard verb forms constitute Huck's most typical mistakes. He often uses the present form or past participle for the simple past tense ... and he often shifts tense within the same sequence." She views "the frequent occurrence of double negatives" as the second most prominent non-standard feature in Huck's speech other than the verb forms. The critic also 
underlines a "redundancy of subjects" as characteristic of Huck's speech patterns. Each of these non-standard features characterizes Jimmy's speech as well (qtd. in Fishkin 9). Huck shifts tenses within a single paragraph or sentence, and this becomes a characteristic of his voice. However, strangely enough, these idiosyncrasies of speech are absent in all Romanian texts:

$\mathrm{N}$-am văzut în viața mea un negru ca el. Dacă îi intra la cap vreo idee, n-aveai cum să i-o scoți nici cu parul. Era așa pornit împotriva lui Solomon că nici nu suporta să mai audă povestinduse despre el. Așa că i-am vorbit de alți regi și l-am lăsat pe Solomon la o parte. I-am povestit de Ludovic al XVI-lea care fusese scurtat cu un cap în Franța și despre băiatul lui, Delfinul, care ar fi fost rege dar l-au prins și l-au zvîrlit în închisoare. ${ }^{3}$ (Brebeanu 85)

The style of Romanian sentences - the cadences, lexicon and syntax are worlds apart from Huck's. The sentences do not evince the repetition of serial verb constructions that characterize Huck's speech in English. They evidence much more subordination and fail to make use of any compensatory techniques that might suggest the style of the original characterized by redundant subjects, the frequent use of present participles in Huck's speech, the recurrent repetitions, or the wrong use of adjectives instead of adverbs (which would be very difficult to render into Romanian, however, since the adjective is identical in form with the adverb).

An observation on style in translation is important at this stage of our analysis. A translator cannot overlook either the peculiarities of style noticeable in the source language writing or the author's individual style if s/he intends to render the original as a unity of content and artistic form. Contemporary English translator Jean Boase-Beier points out that an understanding of style is very important for literary translation as it can help recreate stylistic effects in the target text similar to those of the original. She correctly points out that "texts have effects on their reader and it is part of the translator's task to gauge (and recreate if appropriate) what gives rise to these effects" ("Stylistics and Translation" 6) 
Furthermore, "readers of the source text and the target text have different cognitive contexts and the styles of both texts reflects this difference" (6). Worth pinpointing is also the suggestion the theoretician comes up with regarding to the translation of dialect which "might be represented in the target-text by a target language dialect, or by explicit commentary such as 'she said in dialect', or by a substitution of social for geographical dialect, or of a different register" ("Stylistics and Translation" 8). We concur with BoaseBeier that the translator may decide to echo the source-text syntax in the target text or to compensate for alliteration or word play by employing different phonological or semantic devices, to treat one stylistic aspect or another as the central strategy of a text. Furthermore, style can be approached, according to Boase-Beier, as a cognitive entity, rather than as a purely textual one. In her seminal book entitled Stylistic Approaches to Translation (2006), the theoretician makes a case for cognitive stylistics, arguing that, just as style expresses what is beyond semantics from a linguistic point of view, so, cognitively speaking, it mirrors a series of choices, originating partly in a cognitive state which has absorbed historical, sociological and cultural influences (147).

Twain's style, however, is a very peculiar one, and it has often been misinterpreted even by American critics. In his article entitled "Twain's Modernism: The Death of Speech in Huckleberry Finn as the Birth of a New Aesthetic," Mika Turim-Nygren makes some very interesting points concerning Twain's style which incorporated "homegrown accents without falling into the obvious affectation of transcribing what was literally said" (124). The critic brings convincing arguments to illustrate his point that Huck's language represents "a stylistic choice rather than a literal transcription" (125) and that the novel's "morality has less to do with how Black and white voices speak to one another, and more to do with the way a white voice comes to speak for all Americans" (126). In other words, Twain's talent should be looked in his taking a minority accent and turning it into a literary language capable of representing the country as a whole. Turim-Nygren sheds light on the three techniques used by Twain to achieve his purpose: first, he 
resorted to existing dialect conventions, rather than speech, as the source of Huck's language. Second, he reduced the phonetical misspellings found in previous literary dialect to create a more readable aesthetic which proves unequivocally that his prose has been cut off from speech. Third, Twain inverted the narrative frame found in other dialect fiction, shifting Huck's language outside the quotation marks that had previously contained it and severing all ties with the spoken word. The effect Twain achieves is the reinvention of printed "talk" as a specifically literary mode (TurimNygren 128).

It goes without saying that, with such high stakes, it is extremely difficult to translate the novel and achieve similarity of effect at the level of language where Twain carries out his modern experimentation. However, the translator should strive to understand the style of the original and should do his best to mirror it. Manolachi's translation, for example, displays features of domestication and colloquialism, which lend her translation a natural conversational tonality which corresponds to the original text. Huck's speech establishes him as natural, sincere, without artifice:

N-am mai văzut negru ca ăsta! Dacă-i intra ceva-n cap, nu era chip să i-o mai scoți. N-am pomenit negru să fie aşa de pornit împotriva lui Solomon. Și doar știu destui! Văzând că nu-l pot clinti nicicum, am adus vorba despre alți regi, lăsându-l în pace pe Solomon. I-am vorbit despre Ludovic al șaișpelea, cum îi tăiaseră capul frunțujii acum nu știu câtă vreme. Și despre băiețaşul lui, Delfinul, care trebuia să fie și el rege, dar 1-au băgat la închisoare, şi unii spun c-a și dat ortul popii acolo. (98-99)

The problem, however, is that the Romanian reader does not notice any difference between the dialect of black and white people in the novel since the characters sound alike. The translator should never forget that Twain distinguishes between the speech of white and black characters in the novel on a phonological level (Fishkin 28). Jim speaks just like Huck in the great majority of translations (though Twain's Jim uses non-standard forms for the 
past participle of the past tense, especially with irregular verbs). One also notices the inclusion of too-literary elements together with colloquial ones. However, stylistically colored elements are, at times, successfully created in translations, usually by resorting to omissions of the final sound (especially the definite article), short, colloquial forms, or folk speech:

- Ei, ce zici?Ai mai pomenit așa ceva? Uite-aici puțin. Vezi buturuga aia: Să zicem că-i prima femeie, iar tu ești ailaltă. Jim e Solomon. Și dolaru' ăsta e pruncu'. Și tu vrei copilu', și ea vrea copilu'. Ce fac io atunci? Mă duc prin vecini, aflu al cui e dolaru și-l dau cui i se cuvine, întreg aşa cum tre' să facă orice om cu scaun la cap? Da' de unde! Iau dolaru', îl rup în două, și-ți dau ție jumate și celeilalte femei jumate. Așa a vrut să facă și Solomon cu copilu'. Și-acum, te-ntreb io pe tine: la ce bun juma de hîrtie, dacă nu poți cumpăra nimic cu ea? Și la ce bun juma' de copil? Jim nu dă doi bani pe-un milion de jumătăți de copii. (Manolachi 98)

What also comes as a surprise is that Huck's father speaks equally correct Romanian, which is not the case in the original where double negations, incorrect lexical forms or incorrect syntax are a clear indicator of his illiteracy:

-Să mai zici c-asta-i stăpânire! începu el. Păi, ia uită-te la ea şi zi cam cum e. Ce fel de lege-i aia care-i gata să ia pe fiu de lângă tac-su care 1-a făcut și s-a chinuit să-1 crească pe cheltuiala lui? Da, taman când fiu' ăsta ajunge și el om în toată firea şi-ar putea să muncească și să-nceapă să-și ajute părintele, ca să mai ia și el o pauză, vine legea şi se-mmestecă-n ciorbă. Da stai, c-asta nu-i de-ajuns. Legea-l sprijină pe boșorogu' ăla de Thatcher, judecătoru', ca să mă jefuiască pe mine de avutu' meu. Frumoasă lege, $n$-am ce zice. ${ }^{4}(41-42)$

By way of concluding, we would like to emphasize once more the importance of achieving similarity of effect and authenticity in translation, which are directly related to the style employed by the translator. Openness to its cognitive dimensions - relying on the 
interplay of stylistic universals with stylistic characteristics peculiar to an individual language, culture or view - as well as an increased attention to what is universal and what is culture-specific will help the translator make the right decisions during the translation process. One of these decisions may be to focus more on the way in which the content is expressed. Such an approach is, as we have seen, essential when translating one of the greatest American writers of all time.

\section{Notes:}

${ }^{1}$ The Office for Intellectual Freedom of the American Library Association compiles lists of challenged books based on the reports sent by libraries, schools, and the media regarding various attempts to ban books in communities across the United States. "100 most frequently challenged books: 1990-1999." March 27, 2013.

${ }^{2}$ To say nothing of the translation of humor extensively employed by Twain to explore the subject of race. This subject, however, is too vast to be dealt with in this essay and will probably be analyzed in another article. 3 "I never see such a nigger. If he got a notion in his head once, there warn't no getting it out again. He was the most down on Solomon of any nigger I ever see. So I went to talking about other kings, and let Solomon slide. I told about Louis Sixteenth that got his head cut off in France long time ago; and about his little boy the dolphin, that would 'a' been a king but they took and shut him up in jail" (100).

4 "Call this a govment! why, just look at it and see what it's like. Here's the law a-standing ready to take a man's son away from him- a man's own son, which he has had all the trouble and all the anxiety and all the expense of raising. Yes, just as that man has got that son raised at last, and ready to go to work and begin to do suthin' for him and give him a rest, the law up and goes for him. And they call that govment! That ain't all, nuther. The law backs that old Judge Thatcher up and helps him to keep me out o' my property. Here's what the law does" (28).

\section{Works Cited}

Berthele, Raphael. "Translating African-American Vernacular English into German: The Problem of 'Jim' in Mark Twain's 
Huckleberry Finn.” Journal of Sociolinguistics 4.4 (2000): 588613. Print.

Boase-Beier, Jean. Stylistic Approaches to Translation. London: Routledge, 2006. Print.

---. "Stylistics and Translation." academia.edu. 3 Aug. 2013. Web.

12 Sept. 2020.

Carkeet, David. "The Dialects in Huckleberry Finn." American Literature 51.3 (Nov. 1979): 315-332. Print.

Epstein, B. J. "Translating National History for Children: A Case Study of Adventures of Huckleberry Finn." Ilha do Desterro 71.1 (Jan./Apr. 2018): 103-116. Web. 15 Oct. 2020.

Fishkin, Shelley Fisher. Was Huck Black?: Mark Twain and African-American Voices. Oxford: Oxford UP, 1993. Print.

Hemingway, Ernest. Green Hills of Africa. New York: Scribner, 1935. Print.

Jelliffe, Robert, A. ed. Faulkner at Nagano. Tokyo: Kenkyusha, 1956. Print.

Kehe, Marjorie. “The 'n'-word Gone from Huck Finn - What Would Mark Twain Say? A New Expurgated Edition of Huckleberry Finn Has Got Some Twain Scholars Up in Arms." The Christian Science Monitor 5 Jan. 2011. Web. 12 Sept. 2020.

Pettit, Arthur G. Mark Twain and the South. Lexington, KY: U of Kentucky P, 1974. Print.

Schneider, Ana-Karina. "Literary Translation: Between Mediation and Interpretation." American, British and Canadian Studies 14 (June 2010): 104-118. Print.

Trilling, Lionel. "The Greatness of Huckleberry Finn." Huck Finn among the Critics: A Centennial Selection. Ed. M. Thomas Inge. Frederick, MD: U Publications of America, 1985. 81-92. Print.

Turim-Nygren, Mika. "Twain's Modernism: The Death of Speech in Huckleberry Finn as the Birth of a New Aesthetic." The Journal of Nineteenth-Century Americanists 8.1 (Spring 2020): 123-145. Print. 
Twain, Mark. The Adventures of Huckleberry Finn. London: Penguin, 1994. Print.

---. The Adventures of Huckleberry Finn. Trans. Monica Manolachi. Pref. Lucian Pricop. Ed. a IIa. București: Cartex, 2017. Print.

---. The Adventures of Huckleberry Finn. Trans. Liviu Mateescu. București: Flamingo, 2008. Print.

---. The Adventures of Huckleberry Finn. Trans. Cristina Nicolaescu. București: Ed. Iulian Junior, 2008. Print.

---. The Adventures of Huckleberry Finn. Trans. Alina Loredana Brebeanu. Bucuresti: Ed. MondoRo, 2011. Print.

Venuti, Lawrence. The Translator's Invisibility. A History of Translation. London: Routledge, 2008. Print. 